\title{
SHANGRI-LA AND THE
CURSE OF XI JINPING
Ben Hillman
}

N 2002, the remote Yunnan province county of Zhongdian 中甸 became instantly famous when it officially changed its name to Shangri-la 香格里 拉. ${ }^{7}$ The name change was the centrepiece of a new economic development strategy based on domestic tourism. The largest county in the Diqing Tibetan Autonomous Prefecture, Shangri-la was home to several ethnic groups, Tibetans, Naxi, Yi, Bai, and Han, living side by side in valleys surrounded by snow-capped mountains - a natural and cultural landscape straight out of the pages of James Hilton's Lost Horizon. Allured by the exotic promise of a mythical paradise, and aided by new road and air links, Chinese tourists began flocking to the rural backwater.

As arrivals rose from tens of thousands to hundreds of thousands per year, Shangri-la grew rich, with tour- ism the key to its prosperity. Local officials began building more roads and erecting fences and ticket gates around newly designated tourist sites. They named and re-named places to make them sound more exotic: grasslands at the foot of Shika mountain became known as Blue Moon Valley, and two lakes outside town were incorporated into the new Lakes of Heavenly Arrival national park. Local authorities funded the gilding of temple rooftops within the Tibetan Buddhist monastery at the edge of town and built a new car park to accommodate tour buses. ${ }^{8}$ Officials then commissioned the world's largest Tibetan Buddhist prayer wheel

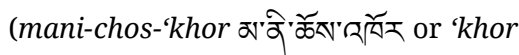
for short) to be mounted on a hill overlooking the town. Later, authorities added a giant stupa at the entrance to the city (municipal status was con- 
ferred on Shangri-la in 2011 following its breakneck urban expansion). In 2017, they decided to double the size of the stupa to make it the world's largest as well. ${ }^{9}$ As tourist numbers continued to swell, grand museums of local culture and history and performance theatres designed in a kitsch, pseudoTibetan style began to replace the town centre's drab government offices, which were relocated to purpose-built sprawling, pseudo-Tibetan complexes on the outskirts of town. Dozens, then hundreds of hotels of all types, from backpacker hostels to five-star luxury resorts, sprang up. Property prices soared, particularly in the 'old town', which was, in fact, a complete reconstruction. ${ }^{10}$

In the early years, some local officials were concerned that the spoils of tourism would flow to a few rich investors and the outsiders they recruited to work in hospitality and other tourism-related businesses because few locals had the skills to find jobs or start new businesses in tourism. Eventually, however, there was enough money sloshing around that just about everyone benefitted. At first, locals with landholdings close to town were able to sell or rent their land at high prices

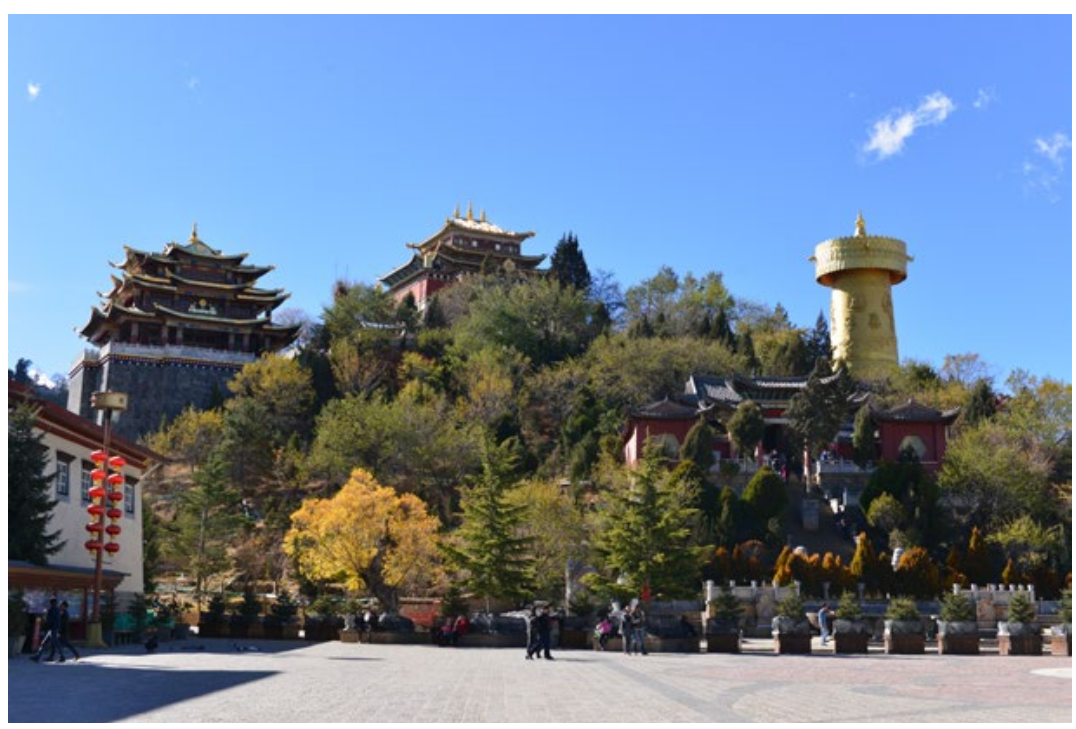

The world's largest Tibetan prayer wheel sits above Shangri-la's new town square Photo: Ben Hillman 
for redevelopment as tourism-based enterprises. With a little help from training projects and social enterprises, others started finding work in hotels, travel agencies, and restaurants. ${ }^{11}$ There was also plenty of demand for local produce so farmers in surrounding villages, who were mostly Tibetan, began to get rich too. Shangri-la's everexpanding streets and residential neighbourhoods started filling up with imported cars. At least two local Tibetan entrepreneurs bought Humvees (High Mobility Multipurpose Wheeled Vehicles). Soon there were also fancy restaurants, bars, and karaoke bars. Local officials dined extravagantly, fuelling a boom in upscale hotels and eateries, including Western-style steakhouses and multi-storey hotpot houses. $^{12}$

And then, all of a sudden, the party stopped. From 2013, Shangri-la's bars and restaurants started to empty. The boom had turned to bust, seemingly overnight. Locals knew who to blame: the newly appointed General Secretary of the Chinese Communist Party, Xi Jinping. Xi came to power at the end of 2012 determined to clean up official corruption, including local profligacy. The Party set new guidelines for official expenditure at all levels, beginning with entertainment and the use of government vehicles. Expenses had to be within budget, conform to strict regulations (including how many dishes were allowed to be served at official functions) and be well documented. Government officials could no longer keep their drivers waiting for them outside nightclubs until the early hours of the morning - and now even being seen to visit 'unsavoury establishments' could ruin careers. Local Party bosses 'got the memo', and official spending dried up. Businesses began to shutter. A policeman told me that all the xiaojie (female sex workers) had left town. (They had mostly been from poorer parts of Yunnan and Sichuan). Locals grumbled about the tough new operating environment even though many acknowledged that the policies were correct and that official spending and corruption had to be reined in.

Soon, fewer and fewer tourists came to Shangri-la. Big groups, the lifeblood of the boom, stopped completely. At first the plummet in tourist arrivals was a mystery. People wondered aloud if the general economic slowdown was to blame. But the dropoff was precipitous. Slowly, it dawned on people that Xi Jinping's policies 
might be responsible for this problem, too; there was a rapid decline in the previously large number of danwei (work unit) tours - groups of state employees enjoying a holiday as a perk of their employment. State-owned enterprises or government bureaucracies sometimes used group tours to reward staff when they were unable increase salaries. Shangri-la was a popular destination for the danwei holiday industry. Danwei groups were big spenders because they were not spending their own money, and tour members had plenty of spare cash to spend on souvenirs such as dried yak meat, and Tibetan medicines such as caterpillar fungus (believed to be an elixir of longevity as well as a cure for all kinds of ailments, including asthma and low libido).

Xi Jinping's regime of strict official discipline forced work units to cut back on perks, such as holidays. As the tour groups stopped coming and hotels and restaurants began to close down, Shangri-la locals began cursing Xi Jinping. 'Xi has definitely screwed us' 搞砸 了我们, a local official told me privately in the lead-up to the Nineteenth Party Congress in 2017. 'For a long time we thought the anti-corruption campaign would eventually come to an end and we could return to business as usual.' However, with Xi Jinping settling into his second term, and with anti-corruption remaining high on his agenda, it now seems that the old business models are defunct, and that money will not grow on trees any more. 'Xi has destroyed our old way of doing business,' the official told me, 'we can only wait to see what a second term of Xi Jinping will bring. $\mathrm{Xi}$ is promising the Chinese people a China Dream, but in Shangrila we are worried the dream is over.' 
This text is taken from China Story Yearbook 2017: Prosperity, edited by Jane Golley and Linda Jaivin, published 2018 by ANU Press, The Australian National University, Canberra, Australia.

doi.org/10.22459/CSY.04.2018.02B 